\title{
Influence of the population density of zooxanthellae and supply of ammonium on the biomass and metabolic characteristics of the reef corals Seriatopora hystrix and Stylophora pistillata
}

\author{
Ove Hoegh-Guldberg*, G. Jason Smith** \\ Department of Biology, University of California Los Angeles, 405 Hilgard Ave, Los Angeles, California 90024-1606, USA
}

\begin{abstract}
In May 1987, the population density of zooxanthellae in the reef coral Seriatopora hystrix around Lizard Island (Great Barrier Reef) varied within and between colonies. This naturally occurring variability made it possible to examine the effect of the population density of zooxanthellae on the physiological characteristics of S. hystrix and its zooxanthellae. As the population density of zooxanthellae increased, the chlorophyll a content and maximum rate of photosynthesis of the zooxanthellae decreased. Phytoplankton studies suggest that cellular chlorophyll content will increase if cells are selfshaded or will decrease if cells are nitrogen-limited. To test the hypothesis that zooxanthellae in S. hystrix and Stylophora pistillata are nitrogen-limited at their highest population densities, colonies of $S$. hystrix and $S$. pistillata with high densities of zooxanthellae were incubated in aquaria to which ammonium (ca 10 to $40 \mu \mathrm{M}$ ) was added at regular intervals. After 3 wk, the population density, chlorophyll a content and maximum rate of photosynthesis of the zooxanthellae had significantly increased, indicating that the biomass of zooxanthellae in reef corals can be limited by the availability of inorganic nitrogen to the association.
\end{abstract}

\section{INTRODUCTION}

Zooxanthellae are dinoflagellate endosymbionts found in all reef-building corals and a wide range of other tropical invertebrates (Trench 1979). In these symbioses, there is an intimate association of host and symbiont metabolism, and a bilateral exchange of inorganic and organic substrates (Cook 1985). One of the more remarkable features of symbiotic associations between invertebrates and zooxanthellae is that they are long-lived and that neither host nor symbiont outgrows the other (Drew 1972). This balance between host and symbiont has prompted several authors to propose that there are regulatory control mechanisms

\footnotetext{
Present addresses:

- Department of Biological Sciences, University of Southern California, Los Angeles, California 90089-0371, USA

-. Department of Molecular Genetics and Cell Biology, University of Chicago, Chicago, Illinois 60637, USA, and Hopkins Marine Station, Pacific Grove, California 93950, USA
}

that maintain the ratio of symbiont to host biomass (Muscatine \& Pool 1979). Little is known about these control mechanisms.

If the population density of zooxanthellae is controlled by the host, then there are several possible points at which control could occur. Muscatine \& Pool (1979) proposed 3 main mechanisms: (1) the expulsion and/or (2) digestion of excess zooxanthellae; and/or (3) the inhibition of the growth of zooxanthellae via either the restricted access to essential nutrients or via the production of growth-inhibiting factor(s), which includes the putative host factor that causes the selective release of metabolites from zooxanthellae (Muscatine 1967). The first 2 mechanisms act on excess zooxanthellae after their production via cell division, and in the few associations that have been investigated, do not appear to be important in regulating the population size of zooxanthellae in 'normal' situations (Fitt \& Trench 1983, Hoegh-Guldberg et al. 1987, Hoegh-Guldberg \& Smith 1989). 
There is indirect evidence that the inhibition of the growth of zooxanthellae (the third category proposed by Muscatine \& Pool 1979) is active as a regulatory mechanism in symbioses between zooxanthellae and invertebrates. Demonstration of a putative 'host factor' that induces zooxanthellae to release organic carbon (Muscatine 1967, Trench 1971) suggests that, by this mechanism, the host may control the size of the carbon pool of the zooxanthellae. Inorganic nutrient supply has also been considered as a point of control although there has been no evidence that unequivocally demonstrates that the host manipulates the supply of inorganic nutrients to the zooxanthellae. Similarly, there is no evidence that the host produces substances that inhibit the growth or division of the zooxanthellae. The observation that the growth rates of zooxanthellae are density-dependent (Hoegh-Guldberg \& Hinde 1986 Smith 1986), with the highest rates of growth occurring at the lowest population densities, suggests that there may be some feature(s) of the host cell environment that inhibits the division of the zooxanthellae at high population densities. Whether or not these features of the host cell environment are part of active host control or merely features of the host cell environment produced by high population densities of zooxanthellae is unclear. Cook \& D'Elia (1987) argue that the population
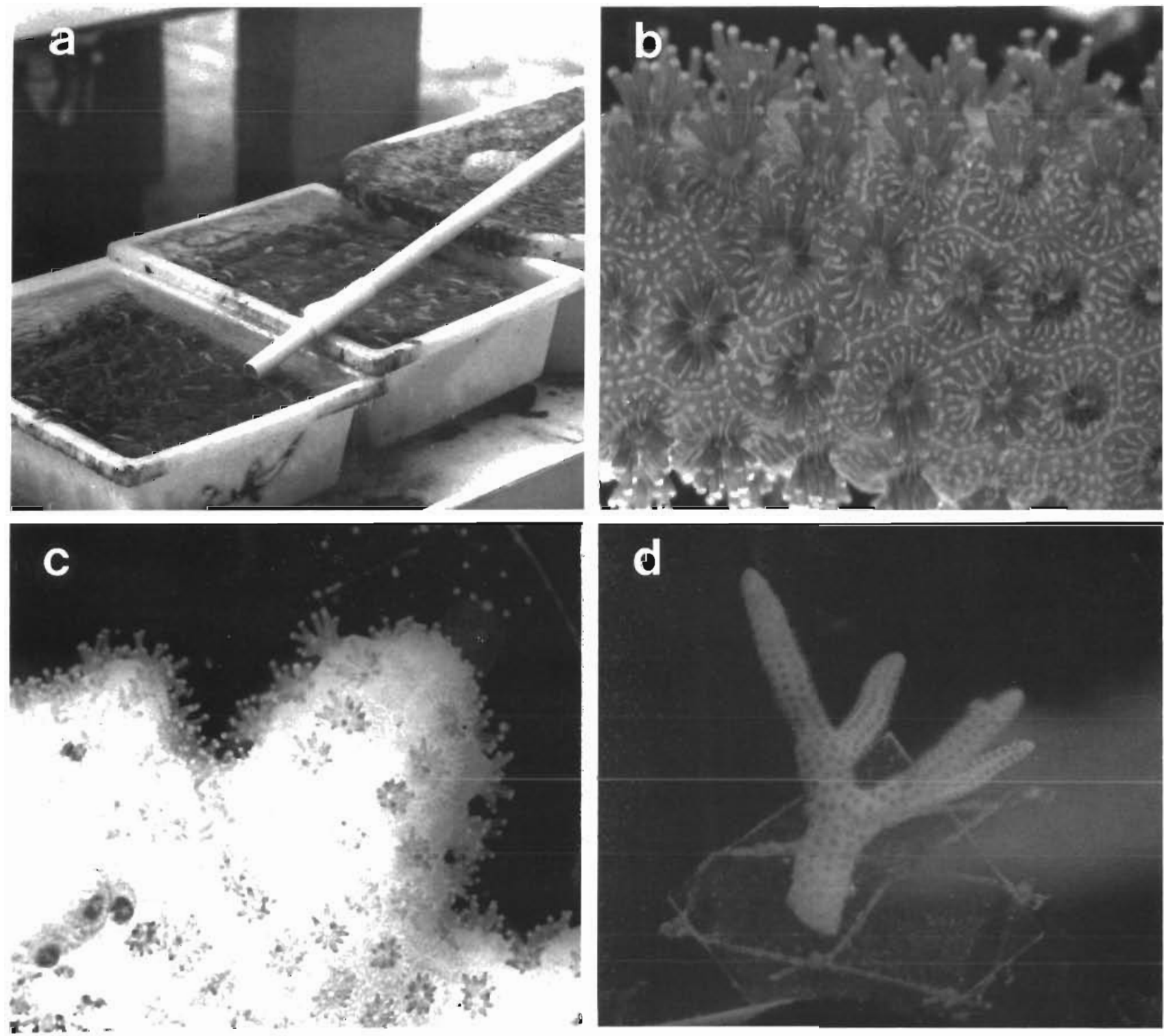

Fig. 1. (a) Flow through seawater aquaria used to maintain daughter colonies (d) after during cultivation from parent colonies of Seriatopora hystrix and Stylophora pistillata. Colonies of $S$. hystrix with. (b) many and (c) few zooxantheliae in their tissues. Colony in (d) is $4 \mathrm{~cm}$ from base to tip 
density of zooxanthellae per unit tissue volume in symbiotic invertebrates is so high normally (in excess of $10^{6}$ cell $\mathrm{ml}^{-1}$ tissue) that the availability of nutrients, such as $\mathrm{NH}_{4}{ }^{+}$originating from host catabolism, would limit the growth of zooxanthellae.

Interestingly, the natural stability characterizing populations of endosymbiotic algae (and hence limited variation in the population density of symbionts) has hampered investigation of putative regulatory mechanisms operating in the maintenance of steady state population densities. The reef corals Seriatopora hystrix and Stylophora pistillata are widespread in the Indo-Pacific region and have been observed to undergo periodic loss of zooxanthellae (Hoegh-Guldberg \& Smith 1989) which has been termed 'bleaching'. During the recovery of colonies following a bleaching event, coral colonies are found to have widely varying population densities of zooxanthellae. Partially bleached colonies provide a natural system with which to explore the influence of symbiont population density on coral biomass and metabolic characteristics. These data along with nutrient enrichment experiment with 'unbleached' corals are used to address the question as to whether the population density of zooxanthellae in reef corals is limited by the availability of inorganic nitrogen.

\section{MATERIALS AND METHODS}

Collection and maintenance of corals. During January-February 1987, colonies of Seriatopora hystrix Dana 1846 growing at Lizard Island, Great Barrier Reef, began to lose zooxanthellae (Hoegh-Guldberg \& Smith 1989). The cause of this phenomenon is unknown although there is evidence that suggests that elevated sea temperatures may be responsible (Glynn 1984). Three months later (May 1987), 2 recovering (partly bleached) and 2 normally pigmented colonies of $S$. hystrix (ca $30 \mathrm{~cm}$ in diameter), and 2 normally pigmented colonies of Stylophora pistillata Esper 1797 , were removed from the substrate, using a mallet and chisel, and transported to the Lizard Island Research Station (L.I.R.S.). The colonies had similar growth morphologies and were selected randomly from populations growing at $5 \mathrm{~m}$ along the edge of the fringing reef opposite Research Beach. These colonies were originally separated from each other by more than $5 \mathrm{~m}$. In the laboratory, ca 20 branch tips ( 3 to $5 \mathrm{~cm}$ length; Fig. 1d) were broken off from each colony and were attached with monofilament netting to microscope slides fitted into small racks and immersed in tubs receiving a continuous supply of seawater (Fig. 1a; Hoegh-Guldberg \& Smith 1989). Incident irradiance (ca $1800 \mu \mathrm{mol} \mathrm{m} \mathrm{m}^{-2} \mathrm{~s}^{-1}$ ) was reduced to $25 \%$ in tanks shaded by black plastic mesh. The tips were left in these tubs for $4 \mathrm{wk}$. The tips from each colony were kept together and separate from the tips originating from the other colonies.

The tips prepared from the partly-bleached colonies of Seriatopora hystrix Ianged from brown to white, due to the varying abundance of zooxanthellae (Fig, 1b,c; Hoegh-Guldberg \& Smith 1989). After 4 wk, coral tissue had grown over the portions of skeleton exposed when tips were broken off the parent colonies. Only those tips (referred to hereafter as colonies) with a complete tissue cover were used in the experiments described below.

Experimental design. Effect of population density of zooxanthellae on the biomass and oxygen flux of Seriatopora hystrix: The effect of variation in population density of zooxanthellae on the biomass and oxygen flux of $S$. hystrix was investigated by closed volume oxygen flux measurements (see 'Measurement techniques', below). This procedure was followed by measurements of the population density, mitotic index and chlorophyll a content of the zooxanthellae; and by the measurement of the soluble protein content and surface area of 14 colonies originating from the first parent colony and 13 colonies from the second parent colony.

Effect of external nutrient supply: The effect of increasing the ambient ammonium concentration was investigated. Ten colonies of Seriatopora hystrix each with about $1.0 \times 10^{6}$ zooxanthellae $\mathrm{cm}^{-2}$ and $10 \mathrm{col}-$ onies of Stylophora pistillata with about $0.5 \times 10^{6} \mathrm{zoo}-$ xanthellae $\mathrm{cm}^{-2}$ were randomly assigned to either of 2 481 aquaria that received a continual supply of fresh seawater $\left(27^{\circ} \mathrm{C}\right.$; flow rate $\left.=193 \pm 15 \mathrm{ml} \mathrm{min}^{-1}, \mathrm{n}=4\right)$. The aquaria received $25 \%$ incident solar irradiance by shading the tanks with black plastic mesh. A solution of $10.0 \mathrm{mM} \mathrm{NH}_{4} \mathrm{Cl}(220 \mathrm{ml})$ was added to one of the tanks (' $+\mathrm{NH}_{4}{ }^{+}$) ) every $6 \mathrm{~h}$ for the first $4 \mathrm{~d}$ and every $12 \mathrm{~h}$ for the next $15 \mathrm{~d}$. Each addition provided an $\mathrm{NH}_{4}{ }^{+}$concentration of $45.8 \mu \mathrm{M}$ which decreased to ca $10 \mu \mathrm{M}$ after $6 \mathrm{~h}$, and to ca $2 \mu \mathrm{M}$ after $12 \mathrm{~h}$ (calculated assuming dilution by the continual inflow and outflow of seawater at the flow rate described above). After $19 \mathrm{~d}$ the incubation was terminated and the colonies removed for the measurement of oxygen flux and biomass (including the cell diameter of zooxanthellae).

Measurement techniques. Closed volume measurement of oxygen flux: The photosynthetic and respiratory rates of colonies were measured using Clark-type oxygen electrodes inserted into small plastic chambers (ca $75 \mathrm{ml}$ ) containing single colonies. Each chamber contained a stirbar powered by a submersible magnetic stirrer ('Variomag' magnetic stirrer, Telesystems Inc.). Light was provided by a dual optic fiber light source (Reichert Scientific Instruments). The colonies were exposed to a series of irradiances and the hyperbolic 
function was used to model the variation of oxygen flux with irradiance. Data were fitted using repeated iterations and the Marqhardt algorithm (Marqhardt 1963).

An Acorn BBC microcomputer was used to collect and analyze data during the experiments. Light was measured using a light-dependent resistor (Cat. \# LDR1, Dick Smith, USA) calibrated with a LI-COR quantum sensor (LI 1935A). Temperature was measured using a small waterproof copper/constantan thermocouple (and electronics employing an AD595 temperature chip, Analogue Devices) mounted on the inside of the chamber. The Clark-type polarographic electrodes were constructed according to the method of Mickel et al. (1983) and, together with the light and temperature sensors, connected via a multi-gain and multi-channel amplifier (Hoegh-Guldberg 1989) to the Acorn BBC computer. Light, temperature and oxygen were measured every $30 \mathrm{~s}$ as described by HoeghGuldberg \& Smith (1989). Each colony was allowed to adjust to chamber conditions for at least 20 min before each experiment. Rates of respiration in the dark were measured in chambers covered with several sheets of black plastic. The oxygen flux of each colony at each irradiance was measured at least twice. Temperature during each experiment was kept between 27 and $28^{\circ} \mathrm{C}$. If temperature increased above $28^{\circ} \mathrm{C}$ or the concentration of oxygen in the chamber decreased below $2 \mathrm{ppm}$, the experiment was terminated and the chamber flushed with aerated seawater. Colonies were allowed to adjust to new chamber conditions for $20 \mathrm{~min}$ before the experiment was restarted. Total changes in oxygen were calculated by multiplying the changes in oxygen concentration by the total volume of the chambers corrected for the volume of the colonies.

Immediately following each experiment, the colonies were placed aside for biomass measurements. Rates of change in oxygen concentration were standardized (1) to the surface area, (2) to the protein content of each colony, (3) to the chlorophyll a content and (4) to the number of zooxanthellae found within a colony. The respiratory rate of each colony (the rate of consumption of oxygen by the colony in darkness, $r_{c}$ ) and the net photosynthetic rate (the net rate production of oxygen of each colony at saturating irradiances, $p_{c}$ nei max $)$, and the ratio of the gross photosynthetic rate $\left(r_{c}+p_{c}\right.$ net max $)$ and the respiratory rate were calculated. The conventions for these quantities are as described by Muscatine (1980), with $\mathrm{p}_{\mathrm{c} \text { gross max }}$ abbreviated to $\mathrm{p}_{\mathrm{c} g \text { max. }}$.

Measurement of biomass parameters: Following oxygen flux measurements, the colonies were placed back in the holding tubs until 09:00 h. At this time, the colonies were removed and blotted on moist tissue paper (to remove excess water) and the tissue on the colonies was removed using a dental Water-Pik
(Deluxe model, Teledyne). The volume of the resulting homogenate was measured, mixed thoroughly and three $2 \mathrm{ml}$ samples stored at $-20^{\circ} \mathrm{C}$ for protein measurement. A $5 \%$ buffered formalin solution $(2 \mathrm{ml})$ was added to another $10 \mathrm{ml}$ subsample of the homogenate, which was set aside for measurement of the concentration and mitotic index (ratio of dividing cells to total cells) of the zooxanthellae in the homogenate. Three $16 \mathrm{ml}$ subsamples were deposited on GF/C (Whatman) filters. The filters were covered with aluminum foil to exclude light and were frozen $\left(-20^{\circ} \mathrm{C}\right)$ until analyzed for chlorophyll a. The total protein concentration of the homogenate was determined using the Hartree (1972) modification of the Lowry protein assay (Lowry et al. 1951). Chlorophyll fluorescence was determined by grinding the frozen filters in $3.2 \mathrm{ml}$ of acetone and centrifuging the resulting solution until clear. The amount of fluorescence due to chlorophyll was measured using a Turner Fluorometer (Model 111; excitation filters: Corning C/S2A and C/S 5-60; emission filter: Corning C/S 2-64). Specific fluorescence measurements were determined from the concentration of chlorophyll a $\left(r^{2}=0.90\right)$ measured in 30 samples using the methodology of Jeffrey \& Humphrey (1975).

The concentration of zooxanthellae and the homogenate was measured using a hemacytometer (BrightLine, American Optical Corp.) and 8 replicate cell counts. The mitotic index was determined by counting the number of dividing cells in 3 samples of 500 zooxanthellae. In a separate study, the variation of mitotic index over a diel cycle was examined by sampling 2 colonies (collected and maintained as described above) every $3 \mathrm{~h}$. In addition, 2 sites within each colony of Seriatopora hystrix were examined. The first site was restricted to within $0.5 \mathrm{~cm}$ of the tip ('tip'), while the second was restricted to an area greater than $3 \mathrm{~cm}$ from the tip ('base').

The specific growth rates and division times of zooxanthellae in Seriatopora hystrix and Stylophora pistillata were calculated using the formulae described by Wilkerson et al. (1983). The diameters of zooxanthellae isolated from $S$. hystrix and $S$. pistillata were determined by photographing zooxanthellae ( $n=500$ cells), using a Leitz photomicroscope and by measuring their diameters from projected images of known magnification. The diameters of the projected images were measured using a linear potentiometer connected to an Acorn BBC computer The potentiometer was calibrated to a precision of $\pm 0.1 \mu \mathrm{m}$.

The surface area of the bare skeletons was measured using the Varathane method of Hoegh-Guldberg (1988) and the aluminum foil method of Marsh (1970). Total protein, chlorophyll a content and zooxanthellae number were determined by multiplying each sample parameter by the total volume of the homogenate. 


\section{RESULTS}

Effect of population density of zooxanthellae on biomass, respiration and photosynthesis of Seriatopora hystrix

Biomass and oxygen flux parameters followed similar trends in colonies derived from separate parent colonies of Seriatopora hystrix $(p>0.05)$. Consequently, data for the 2 groups of colonies were pooled. Vaiues reported in the following text represent means \pm standard errors of the mean (SEM).

\section{Mitotic index}

The mitotic index of the zooxanthellae within Seriatopora hystrix varied over the diel cycle (Fig. 2). Mitotic indices were highest in the pre-dawn to dawn period

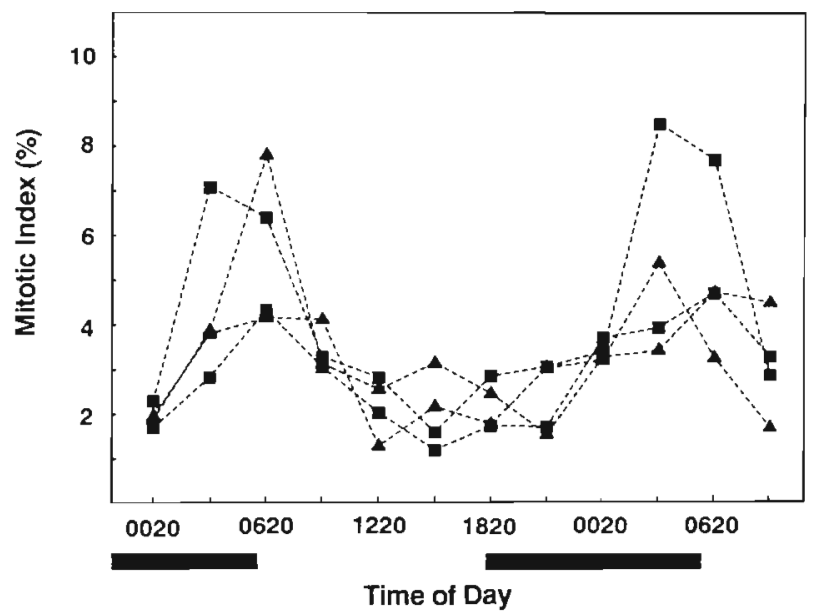

Fig. 2. Seriatopora hystrix. Mitotic index of populations of zooxanthellae as a function of time of day. Data from $2 \mathrm{col}-$ onies area shown: (-) areas within $0.5 \mathrm{~cm}$ of the tip of colony branches (='tips'; Table 1); ( 4 ) areas located $>3 \mathrm{~cm}$ away from branch tips (= 'bases'; Table 1). Points represent mean number of dividing zooxanthellae in 1500 celis. Bars indicate night-time between 03:00 and 07:00 h, and were lowest around 14:00 h. Mitotic indices also varied as a function of location within the colonies of S. hystrix. Populations of zooxanthellae located within $0.5 \mathrm{~cm}$ of the colony branch tips had higher mean mitotic indices (although not significantly so, $\mathrm{p}>0.05$ ) than populations located more basally (Table 1; Fig. 2). Specific growth rates of zooxanthellae within $S$. hystrix varied between 0.0407 and $0.0817 \mathrm{~d}^{-1}$. Because the division of populations of zooxanthellae in $S$. hystrix was phased, the duration of the doublet stage $\left(t_{d}\right)$ could be estimated (Wilkerson et al. 1983, Smith \& Hoegh-Guldberg 1987; Table 1). Estimates of $t_{d}$ for zooxanthellae in S. hystrix were $0.55 \pm$ $0.061 \mathrm{~d}$ and $0.57 \pm 0.050 \mathrm{~d}$ for the first and second day respectively. The mitotic indices ( $\mathrm{Ml}$ ) measured between 09:00 and 12:00 h varied as a function of the population density of zooxanthellae (D) in $S$. hystrix $(\mathrm{p} \leq 0.05, \mathrm{n}=$ 24; Fig. 3).

\section{Chlorophyll a concentration}

The amount of chlorophyll a per area increased with the population density of zooxanthellae $\left(\mathrm{r}^{2}=0.77, \mathrm{n}=\right.$ $28, \mathrm{p}<0.001 ;$ Fig. $4 \mathrm{a}$ ). The amount of chlorophyll a per

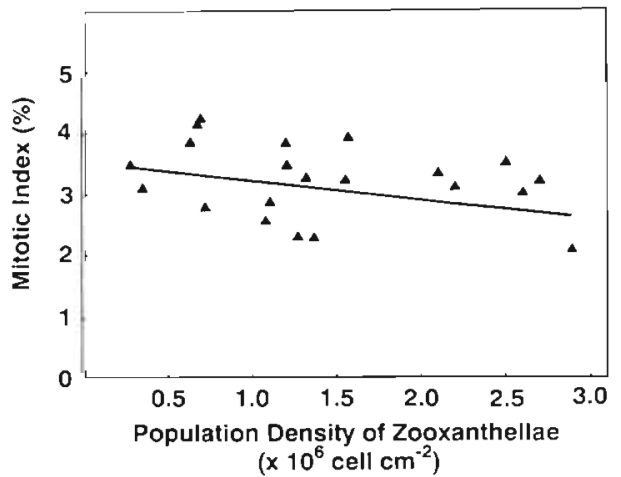

Fig. 3. Seriatopora hystrix. Mitotic index (MI) as a function of the population density of zooxanthellae (D). Points represent number ot dividing zooxanthellae in 1500 zooxanthellae; line is $\mathrm{MI}=3.523-0.326(\mathrm{D}),\left(\mathrm{r}^{2}=0.28, \mathrm{p} \leq 0.05, \mathrm{n}=21\right)$

Table 1. Seriatopora hystrix. Average (MI) and maximal mitotic indices $\left(\mathrm{MI}_{\max }\right)$, and calculated specific growth rates $(\mu)$ and duration of cytokinesis $\left(\mathrm{t}_{\mathrm{c}}\right)$ for zooxanthellae growing in 2 regions of 2 colonies (tip' refers to areas within $0.5 \mathrm{~cm}$ of branch tip, 'base' refers to areas $3 \mathrm{~cm}$ from branch tip, numbers distinguish the 2 colonies sampled). Shown are means \pm standard error of the mean (SEM)

\begin{tabular}{|llcccc|}
\hline Parameter & Day & Base 1 & Tip 1 & Base 2 & Tip 2 \\
\hline $\mathrm{MI}(\%)$ & Pooled & $2.8 \pm 1.17$ & $4.3 \pm 2.39$ & $3.0 \pm 1.25$ & $3.5 \pm 1.65$ \\
$\mathrm{MI}_{\max }(\%)$ & Day 1 & 4.3 & 7.1 & 4.2 & 7.8 \\
& Day 2 & 4.7 & 8.5 & 5.4 & 4.7 \\
$\mu\left(\mathrm{d}^{-1}\right)$ & Day 1 & 0.042 & 0.068 & 0.041 & 0.075 \\
& Day 2 & 0.046 & 0.082 & 0.053 & 0.046 \\
$\mathrm{~T}_{\mathrm{d}}(\mathrm{d})$ & Day 1 & 0.575 & 0.521 & 0.684 & 0.430 \\
& Day 2 & 0.601 & 0.478 & 0.538 & 0.679 \\
\hline
\end{tabular}


zooxanthella varied inversely with the population density of zooxanthellae $\left(r^{2}=0.45, n=28, p<0.01\right.$; Fig. 4 b). Zooxanthellae at the lowest population densities had the highest chlorophyll a contents.

\section{Photosynthesis and respiration}

The net and gross photosynthetic rate per area of colonies of Seriatopora hystrix at light saturation $\left(p_{\mathrm{c}}\right.$ net $\max$ ) increased as a function of the population density of zooxanthellae $\left(\mathrm{r}^{2}=0.80, \mathrm{n}=27\right.$; Figs. 5 and $\left.6 \mathrm{a}\right)$. The respiratory rate per area $\left(\mathrm{r}_{\mathrm{c}}\right)$ tended to increase (though the slope of the line was not significantly greater than 0 ; Fig. 5, p >0.05) with increasing population densities of zooxanthellae. The mean rate of respiration was 31.1 $\pm 4.45 \mu \mathrm{g} \mathrm{O}_{2} \mathrm{~cm}^{-2} \mathrm{~h}^{-1}(\mathrm{~N}=28)$. The ratio of the gross
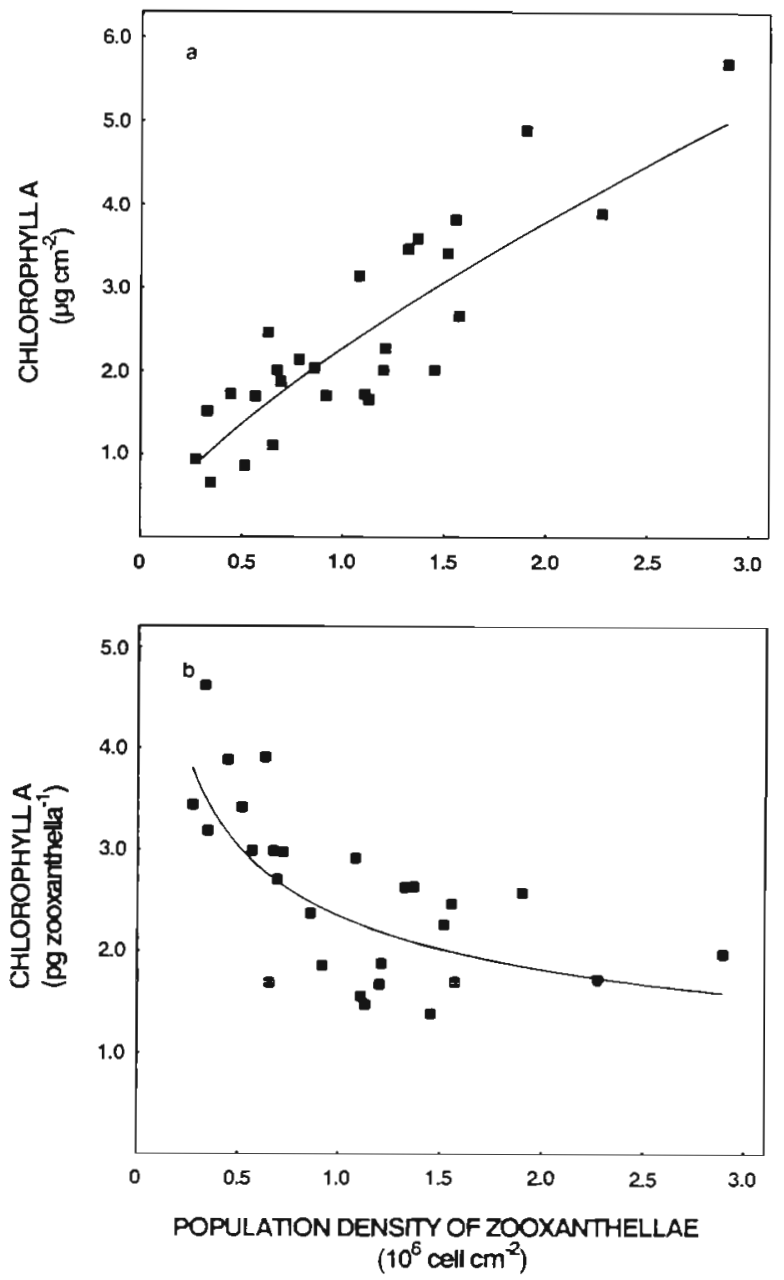

Fig. 4. Seriatopora hystrix. Amount of chlorophyll a (a) per area $(\mathrm{Chl} a \mathrm{~A})$ and (b) per zooxanthella $(\mathrm{Chl} \mathrm{aZ})$ as a function of the population density of zooxanthella. Regression lines are: (a) Ch] $a \mathrm{~A}=2.639(\mathrm{D})^{0.740}\left(\mathrm{r}^{2}=0.78, \mathrm{p}<0.001\right.$. where $\mathrm{p}$ is the probability that exponents are equal to 0) and (b) $\mathrm{Chl} a \mathrm{Z}=$ $2.340(D)^{-0.370}\left(r^{2}=0.45, p<0.01\right)$

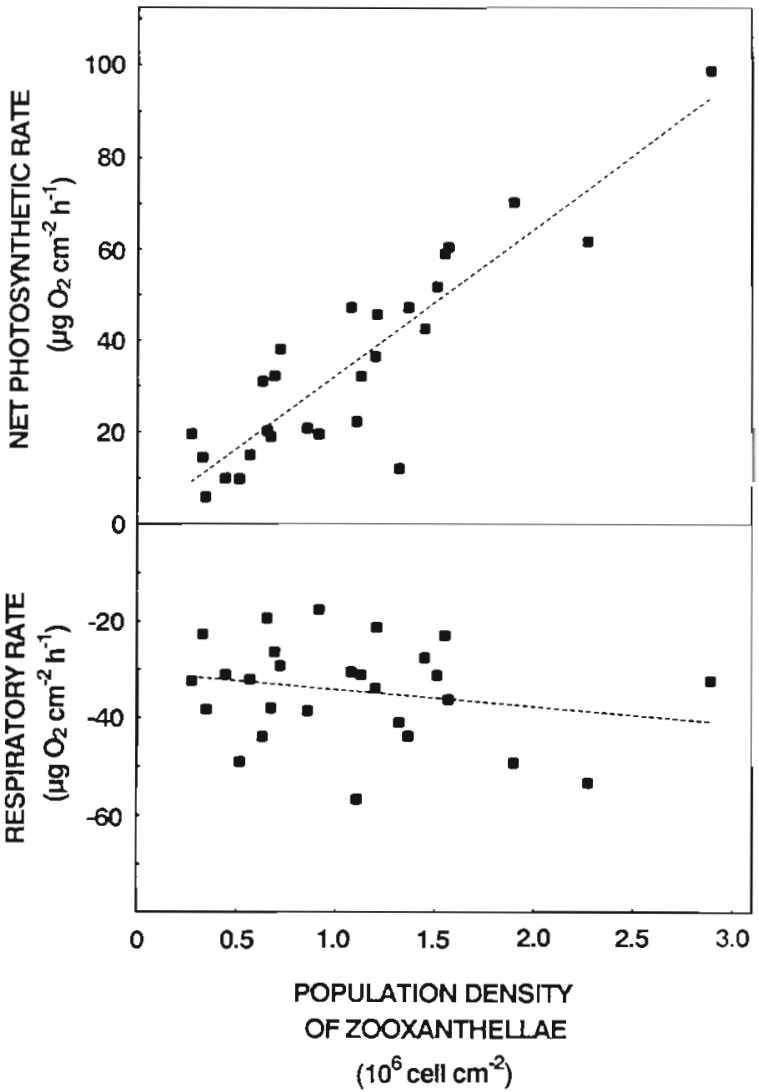

Fig. 5. Seriatopora hystrix. Maximum net rate of photosynthesis $\left(\mathrm{p}_{\mathrm{c} \text { ret max }}\right)$ and colony respiratory rates $\left(\mathrm{r}_{\mathrm{c}}\right)$ as a function of the population density of zooxanthellae (D). Regression lines are: $\mathrm{p}_{\mathrm{c} \text { net } \max }=32.14(\mathrm{D}), \mathrm{r}^{2}=0.80$ and $\mathrm{r}_{\mathrm{c}}=31.06 \pm 4.448$ $\mu \mathrm{g} \mathrm{O}_{2} \mathrm{~cm}^{-2} \mathrm{~h}^{-1}$ (trend not significant, $\mathrm{p}>0.05$ )

photosynthetic rate $\left(p_{c \text { g max }}\right.$ per area) and $r_{c}$ (per area) was linearly related to the population density of zooxanthellae in $S$. hystrix $\left(r^{2}=0.78\right.$; Fig. 7$)$.

The value of $p_{c g}$ max per zooxanthellae cell declined with increasing population density of zooxanthellae (Fig. $6 \mathrm{~b} ; \mathrm{r}^{2}=0.72$ ). This trend paralleled the decline in the chlorophyll a content with population density. Zooxanthellae at the lowest population densities had gross photosynthetic rates that were almost double those of zooxanthellae at the highest population densities. When standardized to chlorophyll $a, p_{c g}$ max did not exhibit any significant variation $(p>0.10)$ with the population density of zooxanthellae and averaged $33.6 \pm 3.16 \mu \mathrm{g} \mathrm{O}(\mu \mathrm{g} \mathrm{chl} \mathrm{a})^{-1} \mathrm{~h}^{-1}(n=28)$

Effect of elevated external $\mathrm{NH}_{4}{ }^{+}$on biomass, respiration and photosynthesis of $S$. hystrix and $S$. pistillata

Biomass parameters

After $19 \mathrm{~d}$ of elevated ammonium, several changes in the biomass and metabolism of Seriatopora hystrix and Stylophora pistillata had occurred. In both species, col- 

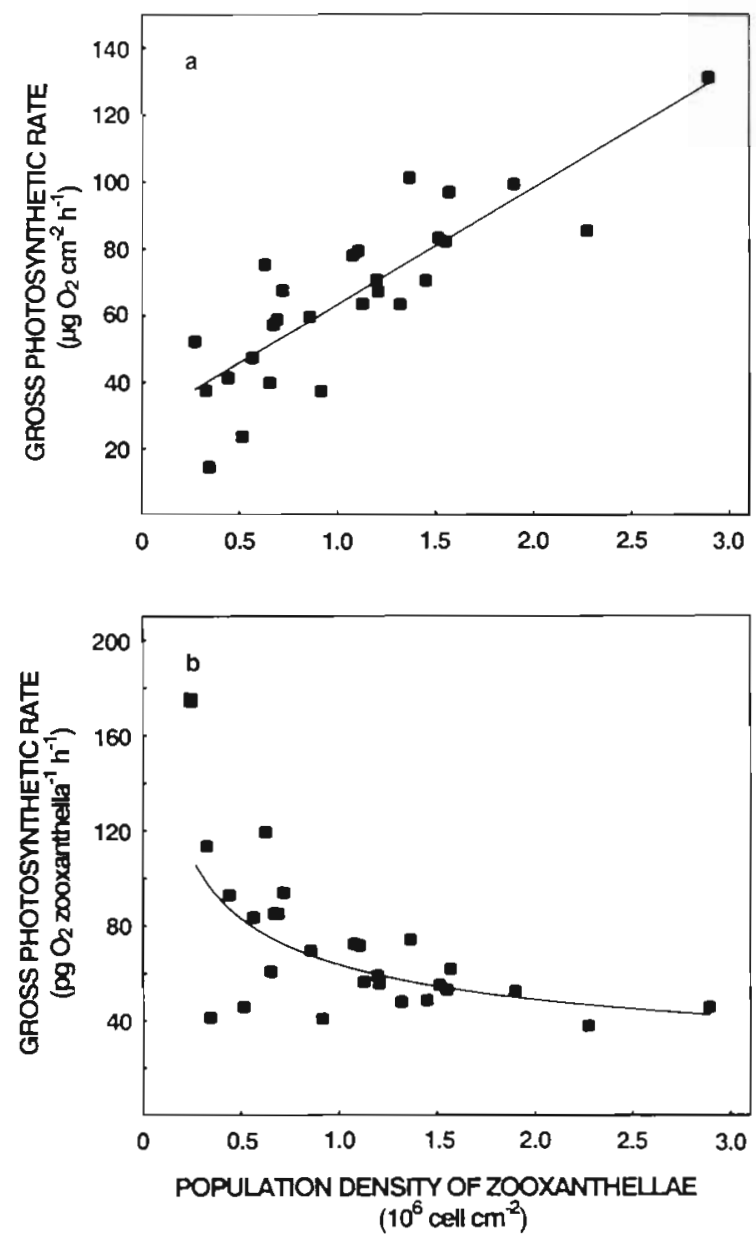

Fig. 6. Seriatopora hystrix. Maximum gross rate of photosynthesis $\left(p_{c} g_{\text {max }}\right.$ ) as a function of population density of zooxanthellae. (a) Results standardized to coral surface area, $p_{c}$ max $\left(\mathrm{cm}^{-2}\right)=35.004(\mathrm{D})+28.088\left(\mathrm{r}^{2}=0.72\right) ;$ and $(\mathrm{b})$ results standardized to zooxanthella number, $p_{c g} \max \left(\right.$ zooxanthella $\left.{ }^{-1}\right)=$ $63.416(\mathrm{D})^{-0.389}\left(\mathrm{r}^{2}=0.38, \mathrm{p}<0.05\right.$ where $\mathrm{p}$ is probability that exponent is equal to 0 )

onies incubated in seawater with elevated ammonium concentrations were darker. This color change was associated with an increased presence of zooxanthellae as indicated by increased chlorophyll $a$ and number of zooxanthellae per surface area (Fig. 8a, b). The chlorophyll a content of zooxanthellae increased with the addition of ammonium ions (31\% increase in S. pistillata, and $90 \%$ increase in $S$. hystrix), although the mean diameter of zooxanthellae was unaffected by elevated ammonium (Fig. 8c, d). The size range of zooxanthellae in colonies receiving ammonium, however, did include larger values than the size ranges of zooxanthellae from untreated corals. Although the amount of protein per coral surface area tended to be higher in corals that received ammonium, the amount of protein per coral surface area was not significantly influenced by the addition of ammonium. Increases in chlorophyll a con-

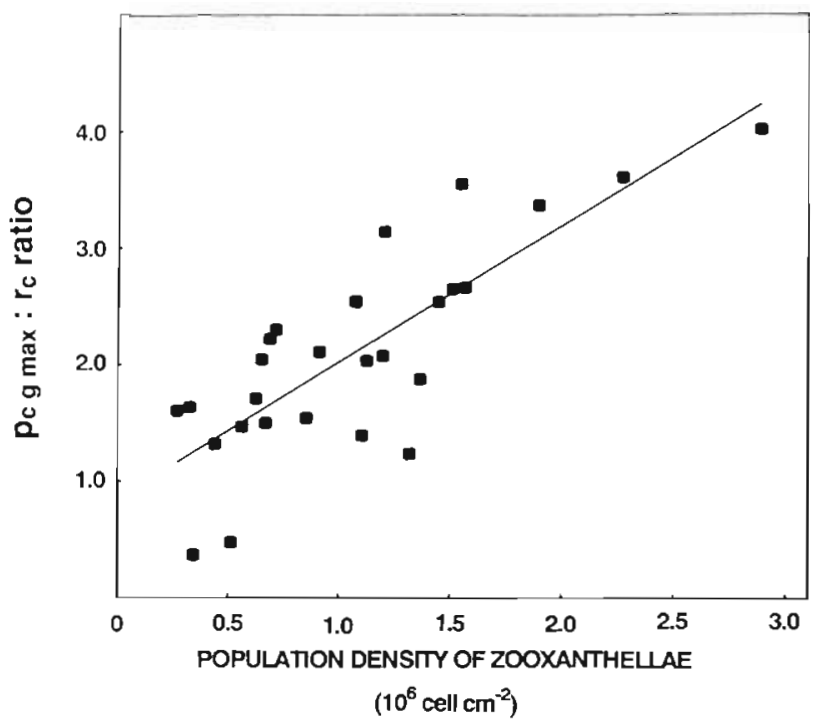

Fig. 7. Seriatopora hystrix. Ratio of maximum rate of gross photosynthesis $\left(\mathrm{p}_{\mathrm{c}}\right.$ gross max and colony respiration rate $\left(\mathrm{r}_{\mathrm{c}}\right)$ as a function of population density of zooxanthellae. Regression line is $\mathrm{p}_{\mathrm{cg} \mathrm{max}} / \mathrm{r}_{\mathrm{c}}=1.171(\mathrm{D})+0.843, \mathrm{r}^{2}=0.65$

tent and the population density of zooxanthellae per unit protein were greater after ammonium enrichment for $S$. pistillata than for $S$. hystrix (Table 2). The average mitotic index, measured at the end of the experiment (Table 2), did not differ between treatments.

\section{Photosynthesis and respiration}

Although the respiratory rates per unit area of both Seriatopora hystrix and Stylophora pistillata were unaffected by the addition of ammonium (with $\mathrm{NH}_{4}{ }^{+}$; Fig. 9a and 10a; Table 3), the photosynthetic response to irradiance of $S$. hystrix and $S$. pistillata was affected. On a per area basis, $P_{\mathrm{cg}}$ max of $\mathrm{NH}_{4}{ }^{+}$-treated colonies was $131 \%$ (S. hystrix, p <0.05; Fig. 9a; Table 3) and $195 \%$ (S. pistillata, $\mathrm{p}<0.05$; Fig. $10 \mathrm{a}$; Table 3 ) that of untreated controls.

The differences between $\mathrm{NH}_{4}{ }^{+}$-treated and control corals were reversed when photosynthetic rates were standardized to chlorophyll a (Figs. 9b and 10b; Table 3). Maximum rates of photosynthesis (photosynthetic capacity) were still significantly different. In both species, however, the gross photosynthetic capacity of $\mathrm{NH}_{4}{ }^{+}$-treated corals was lower than that measured for untreated controls ( $p<0.01$; Table 3). Photosynthetic efficiencies $(\alpha)$ were reduced by the addition of $\mathrm{NH}_{4}{ }^{+}$ $(\mathrm{p}<0.05$; Table 3$)$. Trends were also modified when results were expressed per zooxanthella. In S. pistillata, photosynthetic capacity per cell was reduced when colonies were treated with ammonium. In $S$. hystrix however, photosynthetic capacity per cell was unaffected by the addition of ammonium (Table 3). 


\section{DISCUSSION}

Several lines of evidence suggest that the partially bleached corals used in this study were healthy. Firstly, new tissue grew equally as rapidly on broken ends of fragments that had low population densities of zooxanthellae as on the broken ends of fragments that had high population densities of zooxanthellae (pers. obs.) Secondly, although elevated colony respiratory rates have been associated with exposure to high water temperatures (Coles \& Jokiel 1977, Hoegh-Guldberg \& Smith 1989), respiration rates in this study did not vary as a function of the population density of zooxanthellae (hence extent of bleaching) and were within the range of values reported for Seriatopora hystrix previously (Burris et al. 1983, Hoegh-Guldberg \& Smith 1989). Thirdly, mitotic indices in corals with low population densities of zooxanthellae are higher than the mitotic indices of zooxanthellae in corals with higher population densities, suggesting a healthy rate of division by low density populations of zooxanthellae.

\section{Effect of population density of zooxanthellae on biomass, respiration and photosynthesis of Seriatopora hystrix}

Mitotic index

The proportion of dividing zooxanthellae (mitotic index) in Seriatopora hystrix varies over the diel cycle (Fig. 2). This is indicative of phased cell division (Wil-
Table 2. Seriatopora hystrix and Stylophora pistillata. Average mitotic indices of zooxanthellae, protein concentration, and chlorophyll $a$ and the number of zooxanthellae per protein for colonies incubated in seawater containing elevated ammonia (10 to $40 \mu M)$. Control corals were incubated in normal seawater Shown are means \pm SEM. * (With $\mathrm{NH}_{4}^{-}$) treatments significantly different from controls $(p \leq 0.05)$

\begin{tabular}{|c|c|c|}
\hline Parameter & Control & With $\mathrm{NH}_{4}^{+}$ \\
\hline \multicolumn{3}{|l|}{ S. hystrix } \\
\hline $\begin{array}{l}\text { Mitotic index } \\
(\%)\end{array}$ & $3.2 \pm 0.80$ & $3.1 \pm 0.27$ \\
\hline $\begin{array}{l}\text { Protein per area } \\
\left(\mathrm{mg} \mathrm{cm}^{-2}\right)\end{array}$ & $0.59 \pm 0.323$ & $0.66 \pm 0.600$ \\
\hline $\begin{array}{l}\text { Chlorophyll a } \\
\left(\text { mg g protein }^{-1}\right)\end{array}$ & $8.75 \pm 4.04$ & $13.5 \pm 4.49$ \\
\hline $\begin{array}{l}\text { Zooxanthellae } \\
\left(10^{6} \text { cell mg protein }{ }^{-1}\right)\end{array}$ & $2.11 \pm 1.025$ & $2.78 \pm 1.55$ \\
\hline \multicolumn{3}{|l|}{ S. pistillata } \\
\hline $\begin{array}{l}\text { Mitotic index } \\
(\%)\end{array}$ & $1.6 \pm 0.26$ & $1.1 \pm 0.56$ \\
\hline $\begin{array}{l}\text { Protein per area } \\
\left(\mathrm{mg} \mathrm{cm} \mathrm{cm}^{-2}\right)\end{array}$ & $0.57 \pm 0.281$ & $0.82 \pm 0.357$ \\
\hline $\begin{array}{l}\text { Chlorophyll a } \\
\text { (mg g protein }^{-1} \text { ) }\end{array}$ & * $5.6 \pm 3.14$ & $19.4 \pm 8.97$ \\
\hline $\begin{array}{l}\text { Zooxanthellae } \\
\left(10^{6} \text { cell mg protein }{ }^{-1}\right)\end{array}$ & $* 0.55 \pm 0.124$ & $1.49 \pm 0.248$ \\
\hline
\end{tabular}

kerson et al. 1983). The division of zooxanthellae in the corals Stylophora pistillata, Fungia repanda and Pocillopora damicornis from Lizard Island is also phased (Smith \& Hoegh-Guldberg 1987). These observations are in direct contrast to the observations of Wilkerson et
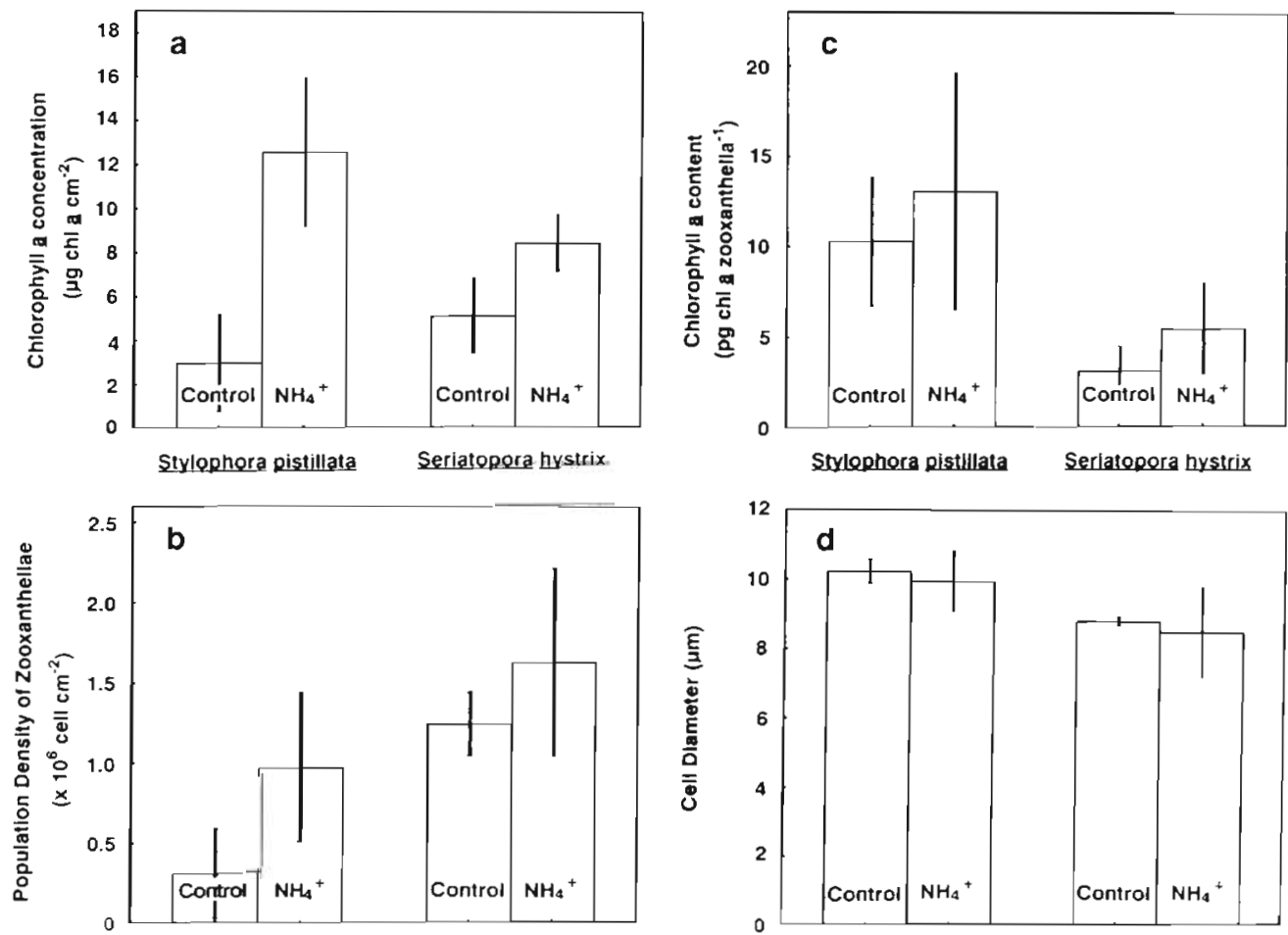

Fig. 8. Stylopora pistillata and Seriatopora hystrix. (a) Chlorophyll $a$, (b) number of zooxanthellae per coral surface area, (c) zooxanthella chlorophyll a content, and (d) cell diameter for colonies incubated in either normal seawater (control) or seawater contaning elevated levels of ammonium ions (ca $20 \mu \mathrm{M}$ ). Bars indicate standard error of the mean 
al. (1988), who reported that zooxanthellae in the tissues of all symbiotic cnidarians studied to date (except zooxanthellae in Mastigias sp.; Wilkerson et al. 1983) lack phased cell division. Wilkerson et al. (1988) proposed that the lack of phased cell division in symbiotic populations of zooxanthellae, normally a characteristic of growth-restricted phytoplankton populations, is due to 'host control and the need to regulate zooxanthellae population density'. Given the prevalence of phased division in zooxanthellae populations from corals collected at Lizard Island, this statement requires reconsideration

Specific growth rates calculated from the mitotic indices measured in this study ranged between 0.040 and $0.082 \mathrm{~d}^{-1}$ for Seriatopora hystrix and 0.028 and $0.032 \mathrm{~d}^{-1}$ for Stylophora pistillata (Table 1). These values compare well with those reported for $S$. pistillata growing in the Red Sea (range 0.013 to $0.094 \mathrm{~d}^{-1}$; Wilkerson et al. 1983, Muscatine et al. 1985) and are lower than the growth rate of zooxanthellae reported previously for $S$. pistillata from the Great Barrier Reef (0.182 $\mathrm{d}^{-1}$; Patton \& Burris 1983). As pointed out by Wilkerson et al. (1988), the majority of symbiotic zooxanthellae fall into the lower growth range, with zooxanthellae from the hydrocoral Millepora dichotoma (Hoegh-Guldberg et al. 1987) and S. pistillata from Patton \& Burris (1983) being exceptionally high.

The mean cell volume of zooxanthellae from Stylophora pistillata is ca $60 \%$ larger than zooxanthel- lae from Seriatopora hystrix. In corals from Jamaica, smaller zooxanthellae have higher growth rates (Wilkerson et al. 1988). Zooxanthellae from $S$. pistillata (larger diameter, slower growth) and $S$. hystrix (smaller diameter, higher growth) show a similar trend. Zooxanthellae in $S$. hystrix also showed higher rates of division in the tips of the coral colony, as described by Wilkerson et al. (1988) for Acropora Cervicornis and Agaricia agaricites. Maximal growth rates of animal tissue have also been reported from regions at the tip of coral branches (Gladfelter 1983). The mitotic index of zooxanthellae in S. hystrix was also lower at the highest population densities of zooxanthellae (Fig. 3). The trend with population density, however, was not as dramatic as that demonstrated for zooxanthellae growing in the nudibranch, Pteraeolidia ianthina (HoeghGuldberg \& Hinde 1986, Hoegh-Guldberg et al. 1986).

\section{Chlorophyll a}

The amount of chlorophyll a per area increased as the population density of zooxanthellae increased (Fig. 4a). Opposing this trend was the decreasing amount of chlorophyll a per algal cell as population density increased (Fig. 4b). This trend has not been reported before for zooxanthellae, and may be indicative of reduced nitrogen availability to zooxanthellae at high population densities. Chlorophyll per cell in algae has

Table 3. Seriatopora hystrix and Stylophora pistillata. Maximum rates of gross photosynthesis $\left(\mathrm{P}_{\mathrm{c} g} \mathrm{max}\right)$, colony respiratory rates $\left(\mathrm{r}_{\mathrm{c}}\right)$ and photosynthetic efficiency $(\alpha)$ standardized to surface area, chlorophyll $a$ and the number of zooxanthellae for colonies incubated in seawater containing elevated concentrations of ammonium ions (10 to $40 \mu \mathrm{M})$. Control corals were incubated in normal seawater Shown are means \pm SEM. * (With $\mathrm{NH}_{4}^{+}$) treatments significantly different from control treatments $(p \leq 0.05)$

\begin{tabular}{|c|c|c|c|c|}
\hline Denominator & & $\begin{array}{c}P_{c g} \max \\
\left\{\mu g O_{2} h^{-1}\right\}\end{array}$ & $\begin{array}{c}\mathrm{r}_{\mathrm{c}} \\
\left(\mu \mathrm{O}_{2} \mathrm{~h}^{-1}\right)\end{array}$ & $\stackrel{\alpha}{a}\left(\mu \mathrm{g} \mathrm{O}_{2} \mathrm{~m}^{2} \mathrm{~s} \mu \mathrm{mol}^{-1} \mathrm{~h}^{-1}\right)$ \\
\hline \multicolumn{5}{|l|}{ S. hystrix } \\
\hline \multirow{3}{*}{$\begin{array}{l}\text { Surface area } \\
\left(\mathrm{cm}^{2}\right)\end{array}$} & With $\mathrm{NH}_{4}^{+}$ & $67.0 \pm 2.74$ & $15.3 \pm 1.38$ & $0.28 \pm 0.030$ \\
\hline & Control & $51.2 \pm 3.06$ & $16.9 \pm 1.80$ & $0.22 \pm 0.042$ \\
\hline & & $*$ & $*$ & $*$ \\
\hline \multirow{2}{*}{$\begin{array}{l}\text { Chlorophyll a } \\
(\mu g)\end{array}$} & With $\mathrm{NH}_{4}^{+}$ & $7.9 \pm 0.30$ & $1.8 \pm 0.15$ & $0.03 \pm 0.004$ \\
\hline & Control & $10.3 \pm 0.51$ & $3.5 \pm 0.31$ & $0.05 \pm 0.008$ \\
\hline \multirow{2}{*}{$\begin{array}{l}\text { Zooxanthellae } \\
\left(10^{6} \mathrm{cell}\right)\end{array}$} & With $\mathrm{NH}_{4}^{+}$ & $41.1 \pm 1.68$ & $9.4 \pm 0.85$ & $0.17 \pm 0.019$ \\
\hline & Control & $41.1 \pm 2.45$ & $13.6 \pm 1.12$ & $0.18 \pm 0.34$ \\
\hline \multirow{4}{*}{$\begin{array}{l}\text { S. pistillata } \\
\text { Surface area } \\
\left(\mathrm{cm}^{2}\right)\end{array}$} & & * & & * \\
\hline & With $\mathrm{NH}_{4}^{+}$ & $54.7 \pm 2.74$ & $13.4 \pm 1.40$ & $0.27 \pm 0.035$ \\
\hline & Control & $28.0 \pm 1.12$ & $12.6 \pm 0.76$ & $0.15 \pm 0.023$ \\
\hline & & $*$ & $*$ & * \\
\hline \multirow{3}{*}{$\begin{array}{l}\text { Chlorophyll a } \\
(\mu g)\end{array}$} & With $\mathrm{NH}_{4}^{+}$ & $4.9 \pm 0.26$ & $1.2 \pm 0.13$ & $0.02 \pm 0.003$ \\
\hline & Control & $9.5 \pm 0.34$ & $4.3 \pm 0.23$ & $0.05 \pm 0.007$ \\
\hline & & $*$ & $*$ & $*$ \\
\hline \multirow{2}{*}{$\begin{array}{l}\text { Zooxanthellae } \\
\left(10^{6} \text { cell }\right)\end{array}$} & With $\mathrm{NH}_{4}^{+}$ & $56.2 \pm 2.82$ & $13.8 \pm 1.44$ & $0.27 \pm 0.036$ \\
\hline & Control & $87.9 \pm 3.51$ & $39.6 \pm 4.51$ & $0.48 \pm 0.72$ \\
\hline
\end{tabular}


been reported to vary with 2 factors. The chlorophyll a content of zooxanthellae has been reported to increase with decreasing ambient light in analogy to sun-shade differences in terrestrial plant communities (Wethey \& Porter 1976, Falkowski \& Dubinsky 1981, Chang et al. 1983, Porter et al. 1984). The reduced availability of inorganic nitrogen has also been demonstrated to reduce the chlorophyll content of marine algae (Falkowski 1980, Dawes et al. 1984, Graneli \& Sundback 1985). Given that the lowest chlorophyll contents are in zooxanthellae living at the highest population densities, the second mechanism provides the best explanation of the variation of chlorophyll per algal cell with population density. As population densities of zooxanthellae increase, light available to resident zooxanthellae would tend to decrease as self-shading by members of the population increases. On the other hand, the nitrogen available to zooxanthellae at the highest densities
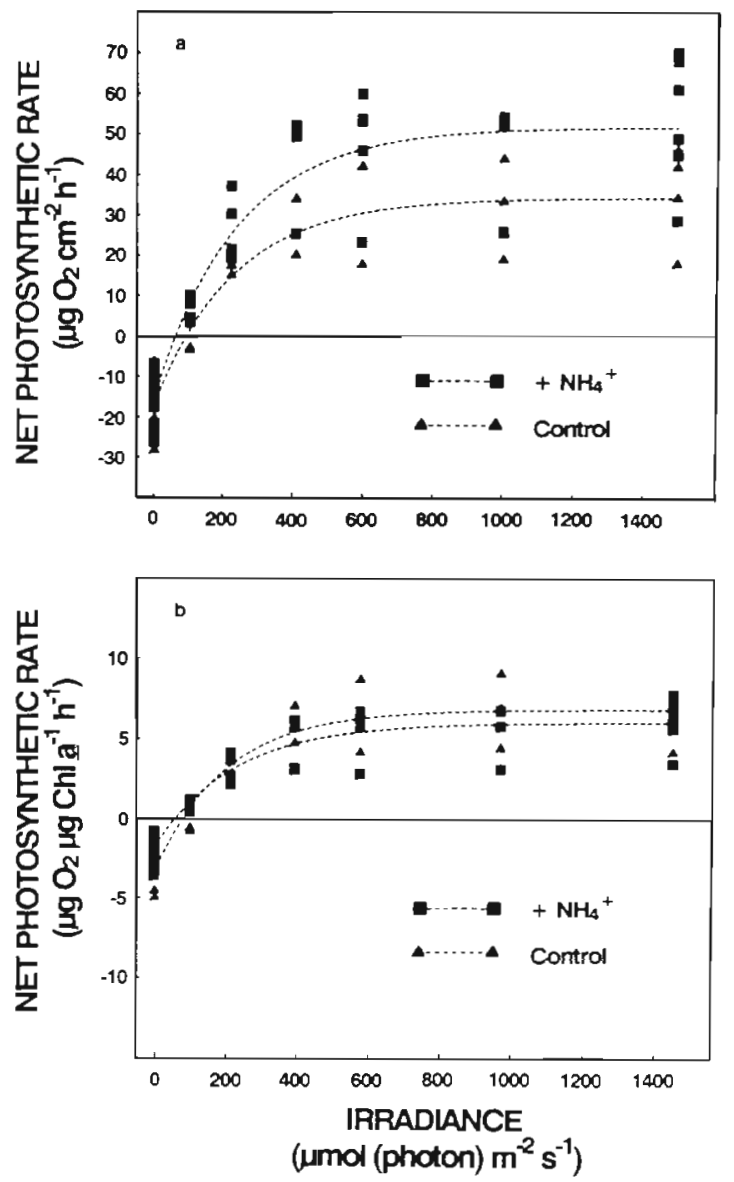

Fig. 9. Seriatopora hystrix. Net rate of photosynthesis as a Eunction of irradiance for colonies incubated in either normal seawater (control) or seawater containing elevated levels of ammonium ions. Top panel shows results standardized to coral surface area and bottom panel shows results standardized to chlorophyll $a$. Regression lines are hyperbolic functions, $p_{c \text { net } \max }=p_{c g \max }\left(1-e^{-\alpha / / p_{c i l} \max }\right)+r_{c}$ the parameters of which appear in Table 3 would be expected to be limiting as discussed by Cook \& D'Elia (1987). Smith (1988) and Cook et al. (1988) found that the chlorophyll content of zooxanthellae in the sea anemone Aiptasia pallida decreased as the host was starved, presumably because of reduced intracellular inorganic nutrient concentrations. Smith \& Muscatine (1986b) and Cook et al. (1988) also reported decreases in mitotic index and population density, and increases in zooxanthella $\mathrm{C}: \mathrm{N}$ ratios, signs that are also indicative of nitrogen limitation.

\section{Photosynthesis and respiration}

The maximum net photosynthetic rate $\left(\mathrm{p}_{\mathrm{c}}\right.$ net max per $\mathrm{cm}^{2}$ ) was strongly dependent on the population density (D) of zooxanthellae in Seriatopora hystrix (Fig. 5; $\mathrm{p}_{\mathrm{cnet} \max }=32.14(\mathrm{D})+0.43, \mathrm{r}^{2}=0.80$ ). The population
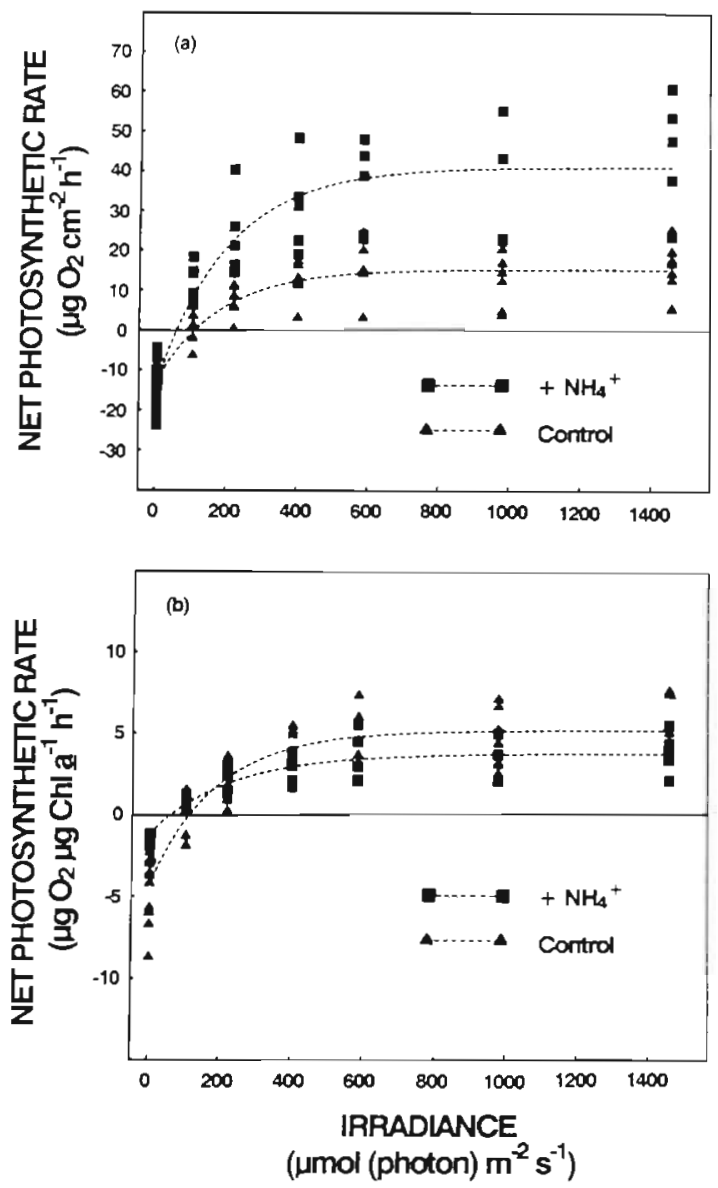

Fig. 10. Stylophora pistillata. Net rate of photosynthesis as a function of irradiance of colonies incubated in either normal seawater (control) or seawater containing elevated levels of ammonium ions. Top panel shows results standardized to coral surface area and bottom panel shows results standardized to chlorophyll a. Regression lines are hyperbolic functions (see legend to Fig. 9), the parameters of which appear in Table 3 
density of zooxanthellae did not significantly influence coral respiration and had a mean value of $31.06 \pm 4.448$ $\mu \mathrm{g} \mathrm{O}_{2} \mathrm{~cm}^{-2} \mathrm{~h}^{-1}$ (Fig. 5). This is in contrast to the increase in the respiratory rate of symbiotic associations associated with increasing population densities of zooxanthellae in anemone (Smith 1984), nudibranch (Hoegh-Guldberg et al. 1986) and coral (Smith \& Muscatine 1986a) associations. In the present study, this trend may have been offset by higher metabolic rates of zooxanthellae at the lowest densities (Fig, $6, a, b$ ). The ratio of $p_{c g \text { max }}$ to $r_{c}$ increased linearly with the population density of zooxanthellae (Fig. 7). From these data, the density of zooxanthellae necessary for $S$. hystrix to be phototrophic with respect to carbon can be calculated. Assuming a photosynthetic quotient of 1.0 and that photosynthetic rates are saturated for $10 \mathrm{~h} \mathrm{~d}^{-1}$, then the population density of zooxanthellae necessary to produce enough carbon for $24 \mathrm{~h}$ for the respiration of both coral host and zooxanthellae is calculated by equating:

$$
10\left(p_{c} g \max \right)-24\left(r_{c}\right)=0 .
$$

As $p_{c} g$ max is equal to the sum of $p_{c \text { net max }}$ and $r_{c}$, this equation reduces to:

$$
p_{c \text { net } \max }=1.4\left(r_{c}\right) \text {, }
$$

and in terms of the population density (D) of zooxanthellae in $S$. hystrix, becomes;

$$
32.14(\mathrm{D})+0.43=43.48 \text {. }
$$

The population density at which $S$. hystrix becomes phototrophic with respect to carbon is then, $1.34 \times 10^{6}$ zooxanthellae $\mathrm{cm}^{-2}$. S. hystrix normally has in excess of $1.6 \times 10^{6}$ zooxanthellae $\mathrm{cm}^{-2}$ (this study) and may have up to $4.78 \times 10^{6}$ zooxanthellae $\mathrm{cm}^{-2}$ (Burris et al. 1983). The fact that population densities of zooxanthellae in 'unbleached' $S$. hystrix are in excess of that necessary for phototrophic maintenance of respiration suggests that the photosynthetic contribution of zooxanthellae can potentially support more than the respiration of the association.

The maximum gross photosynthetic rate per algal cell $\left(\mathrm{p}_{\mathrm{cg} \text { max }}\right)$ in Seriatopora hystrix decreased as the population density of zooxanthellae increased (Fig. 6). The decrease in $p_{c g}$ max was a direct effect of the decreasing chlorophyll content of zooxanthellae as their population density increased, and is supported by the independence of the chlorophyll specific $p_{c g} \max$ from population density effects. On a per chlorophyll a basis, $p_{\mathrm{cg} \max }$ was $33.64 \pm 3.158 \mu \mathrm{g} \mathrm{O}_{2}(\mu \mathrm{g} \mathrm{chl} \mathrm{a})^{-1} \mathrm{~h}^{-1}$.

Effect of elevated external $\mathrm{NH}_{4}{ }^{+}$on biomass, photosynthesis and respiration of $\boldsymbol{S}$. hystrix and $\boldsymbol{S}$. pistillata

The reduction in the chlorophyll content, metabolic rate and growth rate of zooxanthellae with increasing population densities of zooxanthellae in Seriatopora hystrix colonies suggests that density-dependent factors may set an upper limit on zooxanthellae biomass in S. hystrix. Experiments with the long-term enrichment of seawater with ammonium were designed to elucidate the role of the supply of inorganic nitrogen in determining the carrying capacity of reef corals for zooxanthellae.

The repeated addition of ammonium to the flowing water supply of Seriatopora hystrix and Stylophora pistillata colonies over $19 \mathrm{~d}$ resulted in an increase in several biomass parameters, and in colony photosynthetic rates. This is interpreted as direct evidence that the biomass of zooxanthellae in these 2 corals is dependent upon ambient nitrogen supply for a given light regime. These results are in agreement with those of Muscatine et al. (1989) for S. pistillata in the Red Sea, and with Meyers \& Schultz (1985) for Acropora palmata and Porites furcata in the Caribbean.

Biomass parameters

Elevated levels of ammonium increased the average population density and chlorophyll a content of zooxanthellae in both coral species. The large variation of values around each mean, however, indicates that the response was not uniform within each experimental population (Fig. 8). The response to nitrogen enrichment varied between species as well. Although zooanthellae from Seriatopora hystrix and Stylophora pistillata accumulated similar amounts of chlorophyll a per cell during enrichment (ca 2.5 pg cell ${ }^{-1}$ ), the zooxanthellae from $S$. hystrix accumulated a greater amount relative to the starting chlorophyll content. Conversely, the population density of zooxanthellae in ammoniumenriched $S$. pistillata was double that of untreated controls and the relative increase was an order of magnitude greater than that observed in $S$. hystrix exposed to the same enrichment conditions (Fig. 8). These differences resulted in $S$. pistillata colonies experiencing a 3-fold greater increase in chlorophyll a per area than $S$. hystrix during enrichment. The protein content of $S$. pistillata colonies also increased to a greater extent than did the protein content of $S$. hystrix when enriched with ammonium (Table 2).

Despite the dramatic increase in the chlorophyll a content and population density of zooxanthellae in Stylophora pistillata (and to a lesser extent in Seriatopora hystrix), the mitotic index of zooxanthellae was not affected by enrichment with ammonium (Table 2). A similar result was observed for $S$. pistillata from the Red Sea (Muscatine et al. 1989). Recent work by Fitt (1988) and Cook et al. (1988) has shown that both feeding and the addition of ammonium transiently 
stimulate the division frequency of zooxanthellae in the hydrozoan Myrionema amboinense and the sea anemone Aiptasia pallida respectively. This may explain the similarity of the mitotic indices from the 2 experimental treatments in this study. If the growth response of zooxanthellae to a sudden elevation in available nitrogen is short-lived, then sampling the populations after $19 \mathrm{~d}$ may have been too late to observe the response of the mitotic index to ammonium enrichment. An altemative to this hypothesis is that some other factor influencing the population density of zooxanthellae in S. hystrix and S. pistillata varied with the addition of ammonium (e.g. the digestion or expulsion of zooxanthellae; Hoegh-Guldberg et al. 1987, Hoegh-Guldberg \& Smith 1989). The specific expulsion rate of zooxanthellae from $S$. hystrix and $S$. pistillata under control conditions only ranges up to $0.002 \mathrm{~d}^{-1}$ (Hoegh-Guldberg et al. 1987, Hoegh-Guldberg \& Smith 1989) and is an order of magnitude less than the estimated growth rate of zooxanthellae in both $S$. hystrix and $S$. pistillata (Table 1). It is unlikely, therefore, that the increase in the population density of zooxanthellae during enrichment is due to a reduction in the rate at which zooxanthellae are expelled from $S$. hystrix and S. pistillata. In the only study of the expulsion of zooxanthellae during enrichment with inorganic nitrogen, Stimson (1988) reported that the expulsion of zooxanthellae from the coral Pocillopora damicornis increases rather than decreases when coral colonies are incubated in seawater enriched with ammonium.

\section{Photosynthesis and respiration}

Ammonium enrichment induced an increase in the photosynthetic rate per surface area of both coral species. The increase in photosynthetic capacity reflects the increase in the chlorophyll a per area, analogous to the trend seen with changes in the population density of zooxanthellae in Seriatopora hystrix (Fig. 6b). Colony respiration rates were unaffected by the addition of ammonia. The ratio of $\mathrm{p}_{c g} \max$ to $r_{c}$ increased by $45 \%$ and $82 \%$ in $S$. hystrix and Stylophora pistillata, respectively. Presumably, the increase in $\mathrm{p}_{\mathrm{cg} \max } / \mathrm{r}_{\mathrm{c}}$ and the reduction in compensation irradiance (Fig. 10) would eventually lead to increased growth of the colonies under these conditions. In the present study, only $S$. pistillata exhibited an increase in protein biomass during the $19 \mathrm{~d}$ exposure period. Long-term studies involving the fertilization of patch reefs found a $50 \%$ increase in community photosynthesis (Kinsey \& Domm 1974). Meyers \& Schultz (1985) reported an increase in tissue biomass and colony growth rates in corals exposed to the excrement of schooling fish.
Although coral photosynthetic capacities increased, chlorophyll a specific photosynthetic rates and photosynthetic efficiencies declined with ammonium enrichment (Table 3). Photosynthetic rates per cell decreased for zooxanthellae in Stylophora pistillata but were unaffected in Seriatopora hystrix. This trend contrasts that observed with the population density of zooxanthellae in S. hystrix (see the first section of this discussion), where higher cellular chlorophyll was associated with increased photosynthetic capacities. The chlorophyll a accumulated during ammonium enrichment is utilized with reduced efficiency in the photosynthetic performance of the zooxanthellae. This observation may reflect increased shelf-shading at the high densities and high chlorophylla biomass per area obtained during enrichment, and is analogous to the reduction in photosynthetic efficiency and absorptive cross-sectional area observed for zooxanthellae in cave-dwelling $S$. pistillata (Dubinsky et al. 1984, Porter et al. 1984). In the case of cave-dwelling $S$. pistillata, environmental irradiance levels set the upper limit on zooxanthellae density. Clearly, habitat-specific patterns in the population density of zooxanthellae will reflect the long-term balance between the influences of irradiance and nitrogen availability.

\section{Availability of cytosolic inorganic nitrogen and limits to biomass of zooxanthellae in $S$. hystrix and S. pistillata}

Our study provides 2 pieces of evidence in support of the conjecture that the population density of zooxanthellae is limited by the nutrient supply to the corals. First, the decline in chlorophyll a content per zooxanthella with increasing population densities of zooxanthellae in Seriatopora hystrix is similar to the chlorosis experienced by nutrient-limited phytoplankton populations (Falkowski 1980, Dawes et al. 1984, Graneli \& Sundback 1985, Cook et al. 1988). Second, the addition of ammonium to the immediate environment of these corals resulted in a rapid increase in chlorophyll a content and the population density of zooxanthellae in S. hystrix and Stylophora pistillata. The reduction in the photosynthetic performance of the zooxanthellae (associated with the increase in chlorophyll a content per algal cell) does suggest, however, that while the externally supplied nitrogen is available for assimilation, the supply of nitrogen alone is not sufficient to sustain the balanced growth by the zooxanthellae. The question as to whether corals actively regulate the availability of nutrients to zooxanthellae remains unanswered. However, recent evidence supporting the existence of an ammonium-concentrating mechanism in clams and corals (Summons et al. 1986) and the 
identification of a cytosolic NADPH-dependent glutamate dehydrogenase unique to symbiotic corals (Dudler et al. 1987) does suggest that some corals may have the facility to regulate the concentration of ammonium in the immediate extracellular environment of the zooxanthellae.

Acknowledgements. Support for this study was provided by a Lizard Island/Australian Museum Bicentenary Fellowship to O.H.G. and G.J.S. We would like to thank Drs Barbara Kojis, Norman Quinn and the staff of Lizard Island Research Station. We are also grateful to Drs L. Muscatine, R. K. Trench, D. T Manahan, f. G. Morin and R. D. Campbell for suggesting changes to earlier drafts of this manuscript. Special gratitude is due to Dr J. R. B. Lighton for expert help with the computing and electronic aspects of this study. Additional support was provided by NSF no. OCE 8723090 to L. Muscatine.

\section{LITERATURE CITED}

Burris, J. E., Porter, J. W., Laing, W A. (1983). Effects of carbon dioxide concentration on coral photosynthesis. Mar. Biol. 75: 113-116

Chang, S. S., Prézelin, B. B., Trench, R. K. (1983). Mechanisms of photoadaptation in three strains of the symbiotic dinoflagellate Symbiodinium microadriaticum. Mar. Biol. 76 219-229

Coles, S. L., Jokiel, P. L. (1977). Effects of temperature on photosynthesis and respiration in hermatypic corals. Mar. Biol. 43: 209-216

Cook, C. B. (1985). Equilibrium populations and long-term stability of mutualistic algae and invertebrate hosts. In Boucher, D. (ed.) The ecology of mutualism: ecology and evolution. Croon-Helm, London, p. 171-191

Cook, C. B., D'Elia, C. F. (1987). Are natural populations of zooxanthellae ever nutrient-limited? Symbiosis 4:199-212

Cook, C. B., D'Elia, C. F., Muller-Parker, G. (1988). Host feeding and nutrient sufficiency for zooxanthellae in the sea anemone Aiptasia pallida. Mar. Biol. 98: 253-262

Dawes, C. J., Chen, C. P., Jewett-Smith, J., Marsh, A., Watts, S. A. (1984). Effect of phosphate and ammonium levels on photosynthetic and respiratory responses of the red alga Gracilaria verrucosa. Mar. Biol. 78: 325-328

Drew, E. A. (1972). The biology and physiology of algainverieisrate symbioses. II. The density of symbiotic algal cells in a number of hermatypic hard corals and alcyanarians from various depths. J. exp. mar. Biol. Ecol. 9: 71-75

Dudler, N., Yellowlees, D., Miller, D. J. (1987). Localization of two L-Glutamate Dehydrogenases in the coral Acropora latistella. Arch. Biochem. Biophys. 254: 360-371

Dubinsky, Z., Falkowski, P. G., Porter, J. W., Muscatine, L. (1984). Absorption and utilization of radiant energy by light- and shade-adapted colonies of the hermatypic coral Stylophora pistillata. Proc. R. Soc. B 222: 203-214

Falkowski, P. G. (1980). Light-shade adaptation in marine phytoplankton. In: Falkowski, P. G. (ed.) Primary productivity in the sea. Plenum Press, New York, p. 411-419

Falkowski, P. G., Dubinsky, Z. (1981). Light-shade adaptation of Stylophora pistillata, a hermatypic coral from the Gulf of Eilat. Nature, Lond. 289: 172-174

Fitt, W K. (1988). Growth of zooxanthellae and their invertebrate hosts during initial establishment of a symbiosis. Proc. 6th Int. Coral Reef Symp. (Abstracts), p. 30

Fitt, W. K., Trench, R. K. (1983). Endocytosis of the symbiotic dinoflagellate Symbiodinium microadriaticum Fruedenthal by endodermal cells of the scyphistomae of Cassiopeia xamachana and resistance of the algae to host digestion. J. Cell Sci. 64: 195-212

Gladfelter, E. H. (1983). Spatial and temporal patterns of mitosis in the cells of the axial polyp of the reef coral Acropora cervicornis. Biol. Bull. mar biol. Lab., Woods Hole 165: 811-815

Glynn, P. W. (1984). Widespread coral mortality and the 1982/ 1983 El Niño warming event. Environ. Conserv. 11: $133-146$

Graneli, E., Sundback, K. (1985). The response of planktonic and microbenthic algal assemblages to nutrient enrichment in shallow coastal waters, southwest Sweden. J. exp. mar. Biol. Ecol. 85: 253-268

Hartree, E. F. (1972). Determination of protein: a modification of the Lowry method that gives linear photometric response. Analyt. Biochem. 48: 422-427

Hoegh-Guldberg, O. (1988). A method for determining the surface area of corals. Coral Reefs 7: 113-116

Hoegh-Guldberg, O. (1989). The regulatory biology of plantanimal endosymbiosis. Ph. D. dissertation, University of California, Los Angeles

Hoegh-Guldberg, O., Hinde, R. (1986). Studies on a nudibranch that contains zooxanthellae. I. Photosynthesis, respiration and the translocation of newly fixed carbon by zooxanthellae in Pteraeolidia ianthina. Proc. R. Soc. B 228: 493-509

Hoegh-Guldberg, O., Hinde, R., Muscatine, L. (1986). Studies on a nudibranch that contains zooxanthellae. II Contribution to animal respiration (CZAR) in Pteraeolidia ianthina with high and low densities of zooxanthellae. Proc. R. Soc. B 228: 511-521

Hoegh-Guldberg, O., McCloskey, L. R., Muscatine, L. (1987). Expulsion of zooxanthellae by symbiotic cnidarians from the Red Sea. Coral Reefs 5: 201-204

Hoegh-Guldberg, O., Smith, G. J. (1989). The effect of temperature, light and salinity on the population density and export of zooxanthellae from the reef corals Stylophora pistillata and Seriatopora hystrix. J. exp. mar. Biol. Ecol. (in press)

Jeffrey, S. W. Humphrey, G. F. (1975). New spectrophotometric equations for determining chlorophylls a, b, c and c2 in higher plants, algae and natural phytoplankton. Biochem. Physiol. Pflanz. 167: 191-194

Kinsey, D. W., Domm, A. (1974). Effects of fertilization on a coral reef environment - primary productivity studies. Proc. 2nd Int. Coral Reef Symp. 1 49-66

Lowry, O. H., Rosebrough, N. J., Farr, A. L., Randall, R. J (1951). Protein measurement with the Folin phenol reagent. J. biol. Chem. 193: 265-275

Marqhardt, D. W. (1963). An algorithm for least-squares estimation of non-linear parameters. J. Soc. ind. appl. Math. 11: 431-441

Marsh, J. A. (1970). Primary productivity of reef-building calcareous red algae. Ecology 51: 255-263

Meyers, J. L., Schultz, E. T. (1985). Tissue condition and growth rate of corals associated with schooling fish. Limnol. Oceanogr. 30 (1): 157-166

Mickel, T. J., Quetin, L. B., Childress, J. J. (1983). In: Gnaiger, E., Forster, H. (eds.) Polarographic oxygen sensors. Aquatic and physiological applications. Springer-Verlag, Berlin, p. $123-148$

Muscatine, L. (1967). Glycerol excretion by symbiotic algae from corals and Tridacna and its control by the host. Science 156: 516-519

Muscatine, L. (1980). Productivity of zooxanthellae. In: Fal- 
kowski, P. G. (ed.) Primary productivity in the sea. Plenum Publ Corp., New York, p. 381-402

Muscatine, L., Falkowski, P. G., Dubinsky, Z., Cook, P. A., McCloskey, L. R. (1989). The effect of external nutrient resources on the population dynamics of zooxanthellae in a reef coral. Proc. R. Soc. B 236: 311-324

Muscatine, L., McCloskey, L. R., Loya, Y (1985). A comparison of the growth rates of zooxanthellae and animal tissue in the Red Sea coral Stylophora pistillata. Proc. 5th Int. Coral Reef Symp. 6: 119-123

Muscatine, L. Pool, R. R. (1979), Regulation of numbers of intracellular algae. Proc. R. Soc. B 204: 131-139

Meyers, J. L., Schultz, E. T. (1985). Tissue condition and growth rate of corals associated with schooling fish. Limnol. Oceanogr. 30: 157-166

Patton, J. S., Burris, J. E. (1983). Lipid synthesis and extrusion by freshly isolated zooxanthellae (symbiotic algae). Mar. Biol. 75: 131-136

Porter, J. W. (1980). Primary productivity in the sea: reef corals in situ. In: Falkowski, P. G. (ed.) Primary productivity in the sea. Plenum, New York, p. 403-410

Porter, J. W., Muscatine, L., Dubinsky, Z., Falkowski, P. G. (1984). Primary production and photoadaptation in light and shade-adapted colonies of the symbiotic coral, Stylophora pistillata. Proc. R. Soc. B 222: 161-180

Smith, G. J. (1984). Ontogenetic variation in the symbiotic associations between zooxanthellae (Symbiodinium microadriaticum Fruedenthal) and sea anemone (Anthozoa: Actinaria) hosts. Ph. D. dissertation, University of Georgia, Athens

Smith, G. J. (1986). Ontogenetic influences on the carbon flux in Aulactinia stelloides polyps (Anthozoa: Actinaria) and their endosymbiotic algae. Mar. Biol. 92: 361-369

Smith, G. J. (1988). Influences of host ontogeny and nutritional status on zooxanthellae population density and growth rate. Endocytobiosis Cell Res. 5: 125-131

This article was submitted to the editor
Smith, G. J., Hoegh-Guldberg, O. (1987). Variation in the growth rate of zooxanthellae with coral host colony size is not controlled by changes in the duration of cytokinesis EOS (Trans. Am. Geophys. Un.) 68: 1724

Smith, G. J., Muscatine, L. (1986a). Carbon budgets and regulation of the population density of symbiotic algae. Endocytobiosis Cell Res. 3: 213-238

Smith, G. J., Muscatine, L. (1986b). Regulation of zooxanthellae division in symbiosis: the influence of ammonium. phosphate and host feeding. Abstracts of meeting of Am. Soc. Limnol. Oceanogr. University of Rhode Is

Stimson, J. S. (1988). The rate and diel pattern of release of zooxanthellae by undisturbed colonies of Pocillopora damicornis at two levels of dissolved nitrogen. Proc. 6th Int. Coral Reef Symp. Abstracts p. 96

Summons, R. E., Boag, T S., Osmond, C. B., F. R. S. (1986). The effect of ammonium on photosynthesis and the pathway of ammonium assimilation in Gymnodinium microadriaticum in vitro and in symbiosis with tridacnid clams and corals. Proc. R. Soc. B. 227-147-159

Trench, R. K. (1971). The physiology and biochemistry of zooxanthellae symbiotic with marine coelenterates. III. The effect of homogenates of host tissues on the excretion of photosynthetic products in vitro by zooxanthellae from two marine coelenterates. Proc. R. Soc. B 177. $251-264$

Trench, R. K. (1979). The cell biology of plant-animal symbiosis. Ann. Rev. Plant Physiol. 30: 485-531

Wethey, D. S., Porter, J. W. (1976). Sun-shade differences in productivity of reef corals. Nature, Lond. 262: 281-282

Wilkerson, F. P., Kobayashi, D., Muscatine, L. (1988). Mitotic Index and size of symbiotic algae in Caribbean reef corals. Coral Reefs 7: 29-36

Wilkerson, F. P., Muller-Parker, G., Muscatine, L. (1983). Temporal patterns of cell division in natural populations of endosymbiotic algae. Limnol. Oceanogr. 28: 1009-1014

Manuscript first received: March 9, 1989

Revised version accepted: June 22, 1989 